\title{
The Ten Spheres of Al-Farabi: A Medieval Cosmology
}

\section{Amelia Carolina Sparavigna'}

\author{
${ }^{1}$ Department of Applied Science and Technology, Politecnico di Torino, Torino, Italy
}

\begin{abstract}
Abu Nasr Al-Farabi, who lived in the ninth century, left a valuable heritage for Islamic thinkers after him. In the framework of his metaphysics, he developed a theory of emanation describing the origin of the material universe. Ten intellects or intelligences are coming in succession from the First Being, and, from each of them, a sphere of the universe is produced. The first intellect created the outermost sphere and a second intellect. From this second intelligence, the sphere of the fixed stars and a third intellect had been generated. The process continues, through the spheres of the planets, downwards to the sphere of the Moon. From the Moon, a pure intelligence, defined as the "active intelligence", provides a bridge between heavens and earth. In the paper, we discuss this cosmology, comparing it to the cosmology of Robert Grosseteste, an Oxonian thinker of the thirteen century.
\end{abstract}

Keywords: Al-Farabi, Robert Grosseteste, Medieval Cosmology, Medieval Science

\begin{abstract}
1. Introduction
During the Middle Ages, the philosophers and scientists of the Muslin countries were leaders in many sciences, such as geography and astronomy, mathematics and philosophy. They deeply influenced not only the scientific disciplines in Europe, but also literature and arts [1]. To have an example of their ascendancy on the Western culture, we can consider the wide circulation of a work, known as the Compendium of the Science of Stars, written before 850 CE by Al-Farghani. The book, translated into Latin, was so popular that, while producing his Divine Comedy, Dante Alighieri looked at AlFarghani's book like an inspiration for his astronomy and cosmology [2].
\end{abstract}

Besides Al-Farghani, other thinkers from Muslin countries influenced the cosmology of the Western Europe during the twelfth and thirteenth centuries. They formed the wide range of sources from which Robert Grosseteste, at Oxford, created his cosmogony too. Grosseteste was educated in the late twelfth century, and his major works date from the first half of thirteenth century. In [3], we have discussed the treatise where Grosseteste is proposing a universe created by the light expanding from an initial dimensionless point source. He proposed a geocentric universe, like the Ptolemaic world (see Figure 1), with ten spheres, nine of which are the perfect spheres of heavens; below the Moon, there is a sphere containing the four spheres of elements and the earth.

From the initial dimensionless point, Grosseteste imagined a spiritual light flowing and expanding itself. This light forms the matter, giving its corporeity. After the perfection of the first outermost sphere, a luminosity generated in it, condensed a second sphere inside. The second created a third sphere inside and so on, in succession, downwards to the sphere of the Moon. The theory of ten spheres having an origin in succession from the First Being, was not original but coming from Arabic commentaries. We can find it in the cosmology of AlFarabi, who was elaborating earlier Aristotelian and neo-Platonic traditions. However, Grosseteste proposed his theory with the original idea of a spiritual light responsible for the creation of the first sphere, emerging from a dimensionless point [3].

In this paper, after a brief discussion on the role of the thinkers of the Muslim countries in the development of the medieval cosmology, we will discuss the Al-Farabi's thought on the creation of the world.

\section{From Muslim world to Western Europe}

It is probable that the works of the thinkers of Muslim countries came to Western Europe during the Middle Ages following many ways. One of them was through the Spain. This movement of ideas from the East culminated in the thought of Thomas Aquinas, whose position corresponded in some ways to that of Al-Farabi; as told in [4] we can see great similarities between them. Correspondences can be find between Thomas Aquinas and Avicenna too, though they did not always agree [5].

In 1085 Toledo, the greatest of Muslim center of learning founded in the West, fell to the Spanish Christians. There, on initiative of Raymond, Archbishop of Toledo, it was established a school of 
translation. This school flourished and became quite important [5]. A prominent translator in Toledo was the Italian Gerard of Cremona. Called the father of Arabism in Europe, he was born in Cremona in 1114: by the time of his death in 1187 he had produced as many as eighty translations. Among the authors that he put into Latin we have Al-Kindi, Al-Farabi and Avicenna [5]. Also the school of Sicily was very active in the translation of many mathematical, astronomical and astrological books into Latin. The Latin versions of Arab books immediately became the subject of study at Bologna, Montpellier, Paris and Oxford, among other seats of European learning in the twelfth century [5]. Generally, it may be said that the first two, Bologna and Montpellier, concentrated primarily on medicine, while Paris and Oxford were interested in philosophy and theology [5].

The Arabic literature, available in Latin, became a decisive factor in the three cultural movements that started a general awakening and progress in the thirteenth century. They were the growth of the universities out of the old cathedral schools, the discovery and appropriation of Aristotle's thought, and the new activity of Dominican and Franciscan monks [5]. Italy had been more interested in law and medicine, whereas at the University of Paris and later at Oxford the chief subjects were theology and philosophy. By $1250 \mathrm{CE}$, these universities were in full possession of almost everything of the culture from the Muslim countries that had been transmitted thought Spain and North Africa. And then, the medieval knowledge in the Western Europe became composed of patristic materials, early Platonic and Aristotelian translations, such as those of Boethius, and the Arab works [5].

As told in [5], William of Auvergne (d. 1249) is an example of a thinker "deeply imbued by the spirit as well as the letter of the new learning that had been transmitted by way of Spain". By 1225 , he worked at the University of Paris, and in his writings he was quoting extensively from Arab and Islamic philosophers. He mentioned, among the various authors, Al-Farabi, Avicenna, Ghazali, Averroes, and Avicebron [5]. "The movement away from Plato and towards Aristotle had already started, and we find his preference for the latter being freely expressed. ... Yet when we come to his proofs for the existence of God, we find that, though he (William of Auvergne) is influenced by St Augustine, he is far more influenced by the Islamic philosophers, and most of all by Avicenna. The scholastics of the thirteenth century were to come under exactly the same influences, adopt the same position and use similar arguments" [5].
Almost contemporary with William of Auvergne, we have Robert Grosseteste (c.1175 - 9 October 1253). Grosseteste was Chancellor at Oxford and Bishop at Lincoln. In [5], it is told that in Grosseteste's thought the Islamic influence is "not totally absent, though very diffuse and indefinite". He preferred the scientific subjects such as optics and meteorology, probably gaining information on these subjects from Islamic authors. "Like St Bonaventure and the other Franciscans, he was a devout Augustinian and therefore profoundly imbued with Platonism" [5]; however, as we will see in the following, in developing his cosmology, Robert Grosseteste was probably deeply influenced by Al-Farabi. Before discussing Al-Farabi's thought on God and universe, let us see some general points of the Islamic thought on the creation of the world.

\section{Time and Universe}

In [6], it is explained that the Islamic thought categorizes the entire cosmos into two domains: the Unseen Universe, which is imperceptible to mankind in general, possessing properties unknown to us, and the Observable Universe, perceptible through senses and instruments. The purpose of the existence of the Universe, is for God to become known by human beings; in fact, before the creation, God was known only to himself, because nothing existed but he. This is a general view shared by the three Abrahamic religions: Judaism, Christianity and Islam [6].

The ancient Greek philosophers imagined an universe having an infinite past with no beginning. The medieval philosophers and theologians developed a different concept of the universe, with a beginning and a finite past. Among the very first of these philosophers, we find John Philoponus, who lived approximately from 490 to $570 \mathrm{CE}$, also known as John of Alexandria [7]. He presented some arguments against the notion of an infinite past, that were adopted by many thinkers, such as Al-Kindi, Saadia Gaon and Al-Ghazali (Algazel) [6].

Al-Ghazali (c. 1058-1111), in his "The Incoherence of the Philosophers", defends the Ash'ari doctrine of a created universe that is temporally finite, against the Aristotelian doctrine of an eternal universe. In doing so, he proposed that the actual world is the best of all possible worlds that God could have possibly created. It seems that he derived the theory from readings of Avicenna's Metaphysics [6]. Fakhr al-Din Al-Razi (1149-1209) [8], in dealing with his conception of the universe, criticized the idea of the Earth's centrality: it is said that "All praise belongs to God, Lord of the Worlds". Therefore he raised the question of whether the term "worlds" refers to "multiple worlds within this single universe or cosmos, or to many other universes or a multiverse beyond this known universe" [8]. In fact, Al-Razi 
rejected the Aristotelian notion of a single universe revolving around a single world. This rejection was coming from the atomism proposed by the Ash'ari school of Islamic theology, which is involving the existence of a vacant space in which the atoms move, combine and separate [8]. He discussed in greater detail the void, the empty space between stars and constellations in the Universe, and that there is an infinite outer space beyond the known world, and that God can fill this space with an infinite number of universes [6].

\section{Al-Farabi}

Al-Farabi, known in the West as Alpharabius [9], was a renowned scientist and philosopher of the Islamic Golden Age. He was also a cosmologist, logician, and musician. Through his commentaries and treatises, Al-Farabi became well-known among medieval Muslim intellectuals as "The Second Teacher", that is, the successor to "The First Teacher", Aristotle. His name was Abu Nasr Muhammad ibn Muhammad Farabi, as the earliest and most reliable sources are telling [9].

He was born probably in $872 \mathrm{CE}$, in the Greater Khorasan; he dead between 14 December 950 and 12 January 951 in Damascus. Until the devastating Mongol invasion of the thirteenth century, Khorasan was the cultural pole of the world: it produced scientists such as Avicenna, Al-Farabi, Al-Biruni, Omar Khayyám, Al-Khwarizmi, Albumasar, Alfraganus and many others, widely well-known for their contributions in mathematics, astronomy, medicine, physics, geography, and geology [10].

On the metaphysics of Al-Farabi, in [4] it is told that he argued that "since man knows only what he finds out by his own senses and intelligence, it follows that he has no other way of knowing the divine nature except by observation. And observing the visible world, he perceives certain perfections and imperfections in it". According to Al-Farabi, we can have some knowledge of the nature of God by means of a two-fold process: first, via Remotionis, we remove from God whatever implies defect, as limitation, dependence, mutability; and second, via Eminentiae, we attribute to God in an infinite degree all perfections, such as goodness, wisdom, etc. [4].

\section{Al-Farabi's cosmology}

That God exists is a proven truth; that the world was made is another truth. "The most arduous question is the following: what relation is there between God and the world, the Infinite and the finite? What connection is there between God and matter? Is there a bridge thrust from one side to the other over which God might pass to give matter a determinate form? The dualism of spirit and matter, infinite and finite, constitutes the cosmological problem of
Metaphysics" [4]. To solve the problem, Al-Farabi used the intellects of the Spheres between God and the world. "Thus, he made the many proceed from the One by emanation". From the First Being, the One, comes forth the first intellect called the First Cause. From this first intellect, thinking of the First Being, flows forth a second intellect and a sphere. From the second intellect proceeds a third intellect and a sphere. The process goes on in a succession down to the lowest sphere, that of the Moon. From the Moon flows forth the active intellect. Here, we have the lower end of the supersensible world, where there are the ideas of Plato. These ten intellects, together with the nine spheres, constitute the second principle of Being. The active intellect, which is a bridge between heaven and earth, is the third principle. Finally matter and form appear, and, with these, is closed the series of spiritual existences [4].

Only the first of these principles is unity, while the others represent plurality. The first three principles, God, the intellects of the spheres and the active intellect, are spirits. They are not bodies, nor are they in direct relation with bodies. Therefore, the theory taught by Al-Farabi and other philosophers is a theory based on separate intellects, and originated from a mixture of Aristotelian theories on the motion of heavenly spheres and of the neo-Platonic doctrine of emanation [4].

Al-Farabi believed that the world is the workmanship of an eternal, intelligent being, and then God is the first principle of the world. He also believed that God, in order to make the world, must have had materials to work upon [4]. From this he inferred that an eternal, uncreated matter must have been the material cause of the universe. But, as explained in [4], the matter, Al-Farabi believed, had no form, though it contained many forms in potentiality. "When people say that God created the world, they simply mean that God produced the world out of matter by clothing it with a determinate form. The world is certainly God's work, and though it comes after Him as a world-form, yet it is equal to Him in time or eternal, insofar as He could not begin to work on it in time. The reason for this is that God is to the world exactly what a cause is to its effect. Since the cause in this case is inseparable from the effect, it follows that He could not, in a given moment, start making it. For, if He could, that would simply imply imperfection on His part while He had been trying to achieve His goal. This, of course, is incompatible with the absolute perfection of God" [4].

The eternity of the world and of matter, as held by Al-Farabi and Avicenna, was rejected by Averroes and Maimonides, who preferred a "creatio mundi ex nihilo" [4]. 
6. The intellectual activities of the emanations The word "emanation" comes from the Latin "emanare" meaning "to flow from", and it is the mode by which all things are derived from a First Reality or from a perfect God, by a degradation; at every step of the process, emanated and emanating beings are less pure, less perfect, less divine. Emanationism is opposed to creationism, where the universe is created by God who is separate from creation.

In [11], the author explains the Al-Farabi's theory of emanation in detail. For the sake of simplicity, the theory is divided in two parts: the first concerns the creation of the celestial system, further divided into the becoming of the intellects and the becoming of the celestial (heavenly) bodies, the second explains the creation of the sublunary system. From God eternally emanates an intellect that is similar to Him, as an image of Him. Al-Farabi called this "the second", that is the second existence, and the "first intellect". It is a second level of existence, being God's existence the first one. The first intellect is an incorporeal substance. This intellect undergoes two types of intellectual activity. First, it thinks of its own essence and this results in an act of giving substance, and the existence of the first heaven follows necessarily. Second, it thinks of God, and from this activity a third level of existence comes into being, which is the second intellect. The first intellect is in charge of the motion of the outermost celestial sphere or "first heaven" [11].

The intellect in the third level of existence thinks of its own essence, and as a result of this "substantification", the existence of the sphere of the fixed stars follows necessarily [11]. Second, it thinks of God. As a result, a fourth level of existence follows and comes into existence. "By these two intellectual activities and in the same logical and ontological succession, the rest of the intellects and heavenly bodies come into existence" [11]. This process continues until it reaches the existence of the eleventh intellect: here the existence of intellects comes to an end, and also the coming into existence of the heavenly bodies comes to an end with the sphere of the Moon [11]. Below the Moon, we have the material world of four classic elements, the form and matter, and the changes.

All the celestial bodies move in circles. Since the circle is the perfect geometrical shape, the circular motion is most suitable to the celestial bodies [11]. The most excellent of the celestial bodies is the first heaven: it is one body which moves in one circular direction. Its motion is very fast. The second heaven, that of the fixed stars, is a body containing a number of bodies which have a common motion, and the motion of precession too. From the third to the ninth, each heaven contains one body having its own motion.

\section{The sublunary world}

In [11], it is also explained the Al-Farabi's sublunary world. We have that all the celestial bodies have a common nature, and from this common nature, the prime matter follows necessarily, which is common to everything below the celestial bodies. The first material things that arise are the four elements (fire, air, water, and earth), then bodies of their nature. For instance, we have the "vapors" such as clouds, wind, and other things that are created in the "air". In these elements and physical bodies we find also the "powers". Powers include the power by which the bodies move themselves, an internal force, the power by which they act upon one another, which is an active power, and the power by which they receive one another's action, a passive power [11].

The existence of the corporeal material things has six levels: celestial bodies, human bodies, bodies of animals, plants, minerals, and elementary bodies (the four elements of fire, air, water, and earth). In regard to the incorporeal existence, the first level of existence is God. The second level of existence, which is a second grade of being, is the nine intellects of the spheres. The third level of existence is the active intellect, also called the "holy spirit". This intellect is active in humanity, and unites heaven with the sublunary world [11]. These three levels are purely spiritual and incorporeal. The fourth level of existence is the soul. The fifth level of existence is the form. The sixth level of existence is the matter. The soul, form, and matter are also incorporeal [11]. Let us consider that, in the ancient thought, "incorporeal" was not equivalent to "nonmaterial". In fact, the elements, like water and air, are taken by Aristotle to be "matter" and, at the same time, "incorporeal" [12].

\section{A top-down design}

Aristotle did not consider any theory about creation. In fact, the bringing into existence of all possible beings by a First Being is a fundamental question for religion, and then it must be considered. How is it possible to have an eternal world and, at the same time, a world created by God? Al-Farabi proposed an intermediate position adopting a theory that we can find in the so-called Theology of Aristotle, which are parts of the Enneads of Plotinus [5]. The creation is explained in a Neo-Platonic fashion as successive stages of emanation proceeding from God [5]. As clearly explained in [5], the "creation presupposes possibility, but possibility is not a substance and cannot exist separately and independently. The notion of possibility as an accident can only reside in a subject, and that subject is matter. And we saw how the existence of matter may be shown to be eternal. 
Therefore possibility and creation are co-eternal with matter. Or again, since the priority of the Necessary Being over the world of possible beings was not a priority in time, as the theologians maintained, but like cause over effect, a priority in essence and rank, then God and the world are co-eternal" [5].

And again, how does the world with all its multiplicity proceed from God? The Neo-Platonic theory of emanation is suitable to answer this question, answering through the emanated intelligences. "But how exactly does this act of emanation take place? Thinking or contemplation, for the separate substances, is equivalent to creation and produces the same results. The idea precedes the actual thing. The Necessary Being by an act of pure reflection creates the first intelligence which like Him is one and simple. He ponders His own essence, and from that there results this act of creation. The capacity to think and as a consequence create is not special to the Necessary Being, it is equally true of and shared by the intelligences. And the first intelligence by reflection upon itself, produces the first cause. But there is a difference to be noted. The first intelligence, because it is itself created, is possible in its essence, and necessary only in association with the Necessary Being. In so far as it is necessary, when it reflects upon its essence, the soul of the particular sphere proceeds from it. And in so far as it is possible, when it reflects upon its essence, the body of the particular sphere proceeds from it. It is only in this manner that multiplicity comes to take place. And it is this two-fold feature of the first intelligence that is the cause of it" [5]. In a similar manner a second intelligence emanates and so on. "The process continues in succession until it ends in the intelligence from which our souls emanate, and it is the intelligence of the terrestrial world, and we call it the active intelligence. But why does not the process continue indefinitely creating new and more intelligences and spheres? This is because the world is finite; and the series of emanations stop where the world requires no more intelligences, and where the last presides over the generation and corruption of the elements" [5].

\section{Discussion}

Al-Farabi had an intellectual background that was Islamic, but he knew the Greek philosophy in the classical and Hellenistic forms. Therefore, he attempted to reconcile religion with philosophy. As remarked in [5], Al-Farabi had as his chief source the theology, however he quoted from Plato and Aristotle too, when considering God as First Cause of the existence of the world.

Al-Farabi develops his cosmology, where all things are emanation from the First Cause, clearly along Neo-Platonic lines, though differing in some details [5]. From the First Being there emanate successively ten different intellects and from each of these, there results a sphere. The spheres that come into being from the intellects are, from the first to the last, the First Sphere, the sphere of the fixed stars, the spheres of planets, Saturn, Jupiter, Mars, Sun, Venus, Mercury, and the sphere of the Moon. And this sphere is the last of those in which heavenly bodies move by nature in a circle [5].

The ten spheres of Al-Farabi are those considered by Robert Grosseteste in his cosmology too [3]. According to Grosseteste, from the outermost and perfect sphere, the first one, the others are created inwards by luminosities emanated in succession. Since the models are similar, it is quite possible that Grosseteste knew Al-Farabi's cosmology and that he answered Al-Farabi's theory with his metaphysics of light. In particular, it seems that he adapted AlFarabi's top-down design of the intelligences to the generation and action of the luminosities, which are the entities creating the spheres of universe. Then, it seems that in the Grosseteste's thought, the Islamic influence is more than diffuse and indefinite, as told in [5], but a firm background, on which the Oxonian thinker built his science.

\section{References}

[1] B. Ippolito, L'influenza della cultura araba sul mondo latino medievale, Enciclopedia Treccani, available at www.treccani.it.

[2] Alfragano, Il libro dell'aggregazione delle stelle, secondo il Codice Mediceo-Laurenziano contemporaneo a Dante, pubblicato con introduzione e note da Romeo Campani, Collezione di Opuscoli Danteschi Inediti o Rari, L. Passerini Editore, Firenze, 1910.

[3] A.C. Sparavigna, Robert Grosseteste's Thought on Light and Form of the World, The International Journal of Sciences, 2014, Vol.3, n.4, pp.54-62.

[4] R. Hammond, The Philosophy of Alfarabi And Its Influence on Medieval Thought, 1947, The Hobson Book Press.

[5] Soheil M. Afnan, Avicenna, His Life and Work, 1958, George Allen \& Unwin Limited.

[6] Vv. Aa., Wikipedia, Cosmology in Medieval Islam, available at en.wikipedia.org/ wiki/Cosmology_in_medieval_Islam

[7] C. Wildberg, John Philoponus, in The Stanford Encyclopedia of Philosophy, E.N. Zalta Editor, Fall 2008 Edition.

[8] Vv. Aa., Wikipedia, Fakhr al-Din al-Razi.

[9] Vv. Aa., Wikipedia, Al-Farabi.

[10] A.C. Sparavigna, The Science of Al-Biruni, The International Journal of Sciences, 2013, Vol.2, n.2, pp.52-60.

[11] Mashhad Al-Allaf, The Essential Ideas of Islamic Philosophy: A Brief Survey, 2006, Edwin Mellen Press.

[12] Vv. Aa., Wikipedia, en.wikipedia.org/wiki/Incorporeality. 


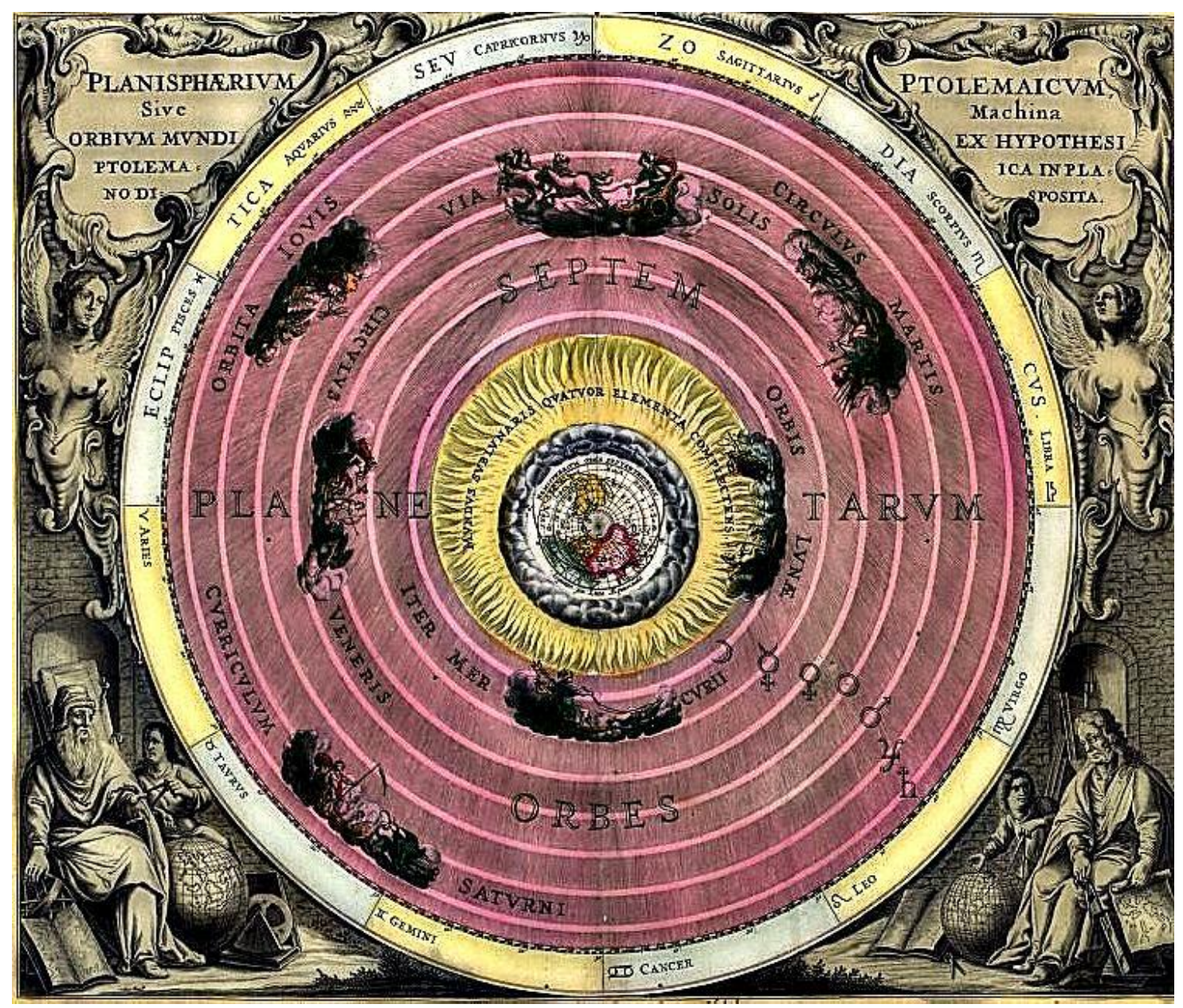

Figure 1 - A Ptolemaic map of the world, created by Andreas Cellarius in 1708. 